Annals of Warsaw University of Life Sciences - SGGW

Land Reclamation No 45 (1), 2013: 17-25

(Ann. Warsaw Univ. of Life Sci. - SGGW, Land Reclam. 45 (1), 2013)

\title{
BAYANAL code in geotechnical design based on Eurocode 7
}

\author{
SIMON RABARIJOELY, STANISŁAW JABŁONOWSKI, \\ KAZIMIERZ GARBULEWSKI \\ Department of Geotechnical Engineering, Warsaw University of Life Sciences - SGGW
}

\begin{abstract}
BAYANAL code in geotechnical design based on Eurocode 7. Geotechnical problems that are characterized by a high degree of complexity and uncertainty with respect to the input data are solved recently, using the Bayesian analysis (for instance the problem of a cautious estimation of the geotechnical characteristic parameters according to the Eurocode 7 requirements). The applicability of the Bayesian approach to geotechnics via a simple examples related to determination of characteristic values of geotechnical parameters for design structures is in the paper addressed. In order to select the characteristic parameters for the geotechnical design a new numerical code called BAYANAL was developed. Example of applying the BAYANAL code to analyse the DMT tests demonstrates that it is a powerful and promising tool in evaluation of ground properties and geotechnical parameters.
\end{abstract}

Key words: Eurocode 7, ground characterisation, geotechnical design, BAYANAL code

\section{INTRODUCTION}

In geotechnical design with respect to rules and principles of Eurocode 7 (EN 1997-1, 2) the selection of geotechnical actions and resistances, particularly characteristic material parameters, is considered as a crucial process creating the difficulties for designers. EN 1997-1 defines the characteristic value as being selected "as a cautious estimate of the value affecting the occurrence of the limit state" (Frank et al. 2004; Pieczyrak 2009; Schuppener et al. 2009;
Wysokiński et al. 2011). For selecting characteristic values of geotechnical parameters the statistical methods are commonly recommended. Deduction in the classic mathematical statistics is based on a random sample drawn from the population. In an alternative approach, derived from the Bayes' theorem (Alén 1998; Alén and Sällfors 1999; Uzielli 2008), deduction can be based not only on a random sample but also on so-called a priori information. A posteriori information is generated from these two sets of data. A priori knowledge may be so-called expert knowledge, it may derive from earlier investigation from which results are known but not all data set. The knowledge's character does not allow us to take advantage of it in the classic approach. Bayesian approach should be used then. If the same data can be used in the both cases, classic and Bayesian analysis would give similar conclusions. Population's parameters to be estimated, e.g. parameter $\theta$ (mean, standard deviation, specified type elements' fraction), are treated differently in the both cases. In the classic approach the parameters' values are particular though not known. If we are dealing with a homogeneous medium (ground), to determine the characteristic values of geotechnical parameters $\left(X_{k}\right)$ the Student's t-95 percent 
confidence level can be used according to the formula:

$X_{k}=X_{m}\left[1-k_{n} V_{x}\right]$

where:

$X_{m}$ - average of soil parameter,

$k_{n}$ - statistical factor,

$V_{x}-$ coefficient of variation.

Schneider (1990, 1997, 2010) and Schneider and Fitze (2009) proposed to assume $k_{n}=0.5$, it means one half a standard deviation below the mean value. The procedure for determination of characteristic value is presented in Figure 1 , where $n$ is the number of samples, and $x_{i}$-parameters in a homogeneous layer.

In the present paper Bayesian analysis has been adapted for a case, when a not known $\theta$ parameter distribution is to be estimated and $\theta$ is the mean in a normal population, however the population standard deviation $-\sigma_{0}$ is known. It is derived from the prior knowledge that the mean $\theta$ is a normal random variable with parameters $m_{1}$ and $\sigma_{1}$. If in turn the average of the $n$-sample drawn from the population is equal to $m_{2}$, a posteriori distribution of the random variable $\theta$ is also normal, with the mean $m$ and the standard deviation $-\sigma$, calculated as follows:

$$
m=\frac{\left(1 / \sigma_{1}^{2}\right) \cdot m_{1}+\left(n / \sigma_{0}^{2}\right) \cdot m_{2}}{\left(1 / \sigma_{1}^{2}\right)+\left(n / \sigma_{0}^{2}\right)}
$$

$$
\sigma=\frac{1}{\left(1 / \sigma_{1}^{2}\right)+\left(n / \sigma_{0}^{2}\right)}
$$

The presented Bayes' theorem gives a valuable practical possibility of successive including of new information, coming from consecutively drawn random samples. On a consecutive step, the knowledge about a posteriori $\theta$ parameter's distribution is treated as a priori knowledge of this parameter. An order of including new portions of information does not affect a final result.

The paper addresses the applicability of the Bayesian approach to determine a characteristic parameters of boulder clays in geotechnical design of the SGGW

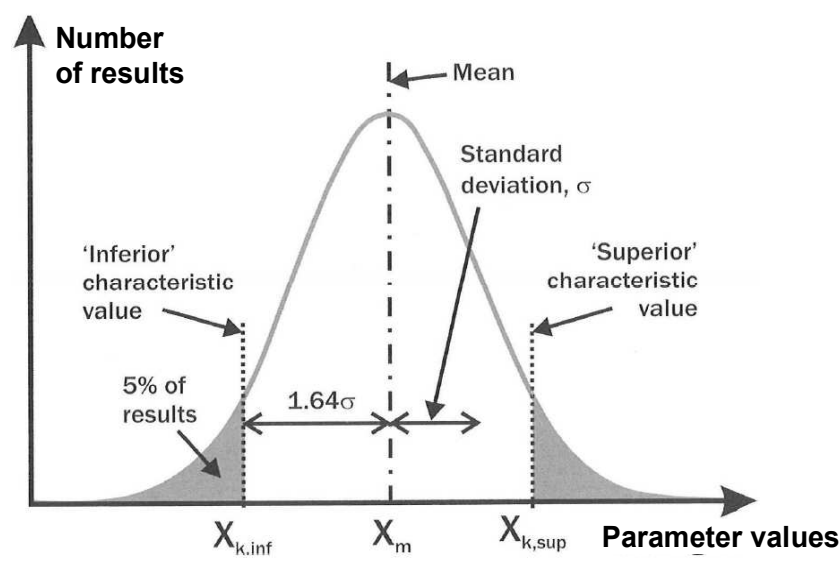

FIGURE 1. Statistical estimation of geotechnical characteristic values (Orr 2005; Garbulewski et al. 2007; Bond and Harris 2008) 
Campus in Warsaw. The selection of the geotechnical characteristic parameters was carried out using the new numerical code called BAYANAL. Overview of BAYANAL code, its assumption and requirement and procedure of statistical analysis had been presented. Finally, the code application in design calculation were described. The BAYANAL code will be helpful in designing and therefore should be recommended to apply in geotechnical practice.

\section{OVERVIEW OF BAYANAL CODE}

\section{Assumptions and requirement}

The basic assumptions and requirements for the BAYANAL code application are as follows:

- full integration with Excel 2003 (or higher) operating in a Windows environment,

- intuitive graphical interface,

- the ability to automatically test of the null hypothesis ("H 0 ") on the normal random variable on the basis of individual tests samples,

- the greatest possible independence of the application code from the source data,

- no interference in the source data,

- easy application of code to different PC computer,

- independence from the schedule of input data in files and sheets,

- a flexible way to select and selecting data to be analyzed,

- the ability to work as interactive and automatic,

- generating detailed reports from the analyzes.
Due to the first two requirements it was chosen implementation of applications based on the Excel spreadsheet in 2003 with the support code in Visual Basic for Applications, and a system of MS Office object libraries (libraries Visual Basic for Applications and Microsoft Office Object Library version 11.0). Application forms/dialog boxes with a comprehensive description of the buttons and functions associated with them, depending on the context and the currently executed thread in the application, provided a clear and intuitive graphical interface. All calculations required to perform the analyzes are conducted by the formula written on a permanent basis to work spreadsheet (invisible to the user). All input data required for the calculation of the iteration is copied to that worksheet to complete separation of data sources and applications.

Automated testing the hypothesis ("H 0") for each sampling requires the integration of this functionality in Excel. Excel does not implement the so-called Shapiro-Wilk test (the test best suited to situations where attempts may be small). Therefore in reality there are two possible solutions:

- connect to the application finished implementing this functionality added,

- table list of coefficients for the Shapiro-Wilk test, adding tables to the application for an additional worksheet and calculate the test result using the array and the standard designs.

The first solution has been chosen because of its easier implementation and the ability to achieve much higher accuracy than the tabulation values and the approximation ones in Excel spreadsheet. 
The application is integrated add-in for Excel for free license for non-commercial use. It is called PopTools and downloads from the website. Other requirements are achieved through the implementation of the application to the algorithm presented in the following chapter.

\section{Procedure of statistical analysis}

The procedure in BAYANAL code consists of:

\section{Step 1:}

- provide initial data by the user, including the ability to select automatic operation,

- specify the file(s) to the data by the user (standard window opening set),

- open of the first file, activate the first sheet.

Step 2:

- identify (or waiting indication) data to analyze the parameters of initial,

- analyse of the data indicated, any error handling specified data range,

- construct of the Shapiro-Wilk test for a random sample indicated, the term action in the event of non-compliance with the Shapiro-Wilk.

Step 3:

- go to the next test/sheet/file in interactive mode or automatic,

- transit to the report generated by the resignation of the opening of the next set of statistical analysis ("Cancel" button in the dialog box to open files),

- close the source files (with the option: "skip shift") and the creation of the report.

\section{User manual}

The main sheet of the BAYANAL code is the sheet "Start" (Field 1-P1) as shown in Figure 2. Data for the analysis must be typed in Excel cell sheets as numbers. The data can be organized into one or more files. Every file can consist one or more data sheets. Data files can be input to the program sequentially or several times. However, in case of several time procedures it is not possible to control the order of opening and analyzing the data from different files; the files are opened in the order imposed by Windows. The data on the other sheets are always evaluated in the order of their entry in the workbook. After the start of the analysis it is not possible to change the order of analysis sheets or return to previously analyzed data. Identification of cells containing one test of a random variable can be done automatically or manually. Automatic selection of data from one sample can be made when they are stored in a default format: "There is only one sample of a random variable on a sheet". A random sample of data are stored in a single column. Headline random data is analyzed cell with the name of the parameter. Termination of the analysis is done by pressing "Cancel" button in the dialog box for opening files.

The BAYANAL code also includes reports previously performed statistical analyzes constituting of one sheet (P2). The names of these sheets are created automatically according to the scheme: "analyzed parameter name" and "date" (no year), and "time" of the analysis and formatted as shown in the P2. Sheets reports of the analyzes can move, copy and delete according to standard Excel commands. The work begins with an application of the button P3. 


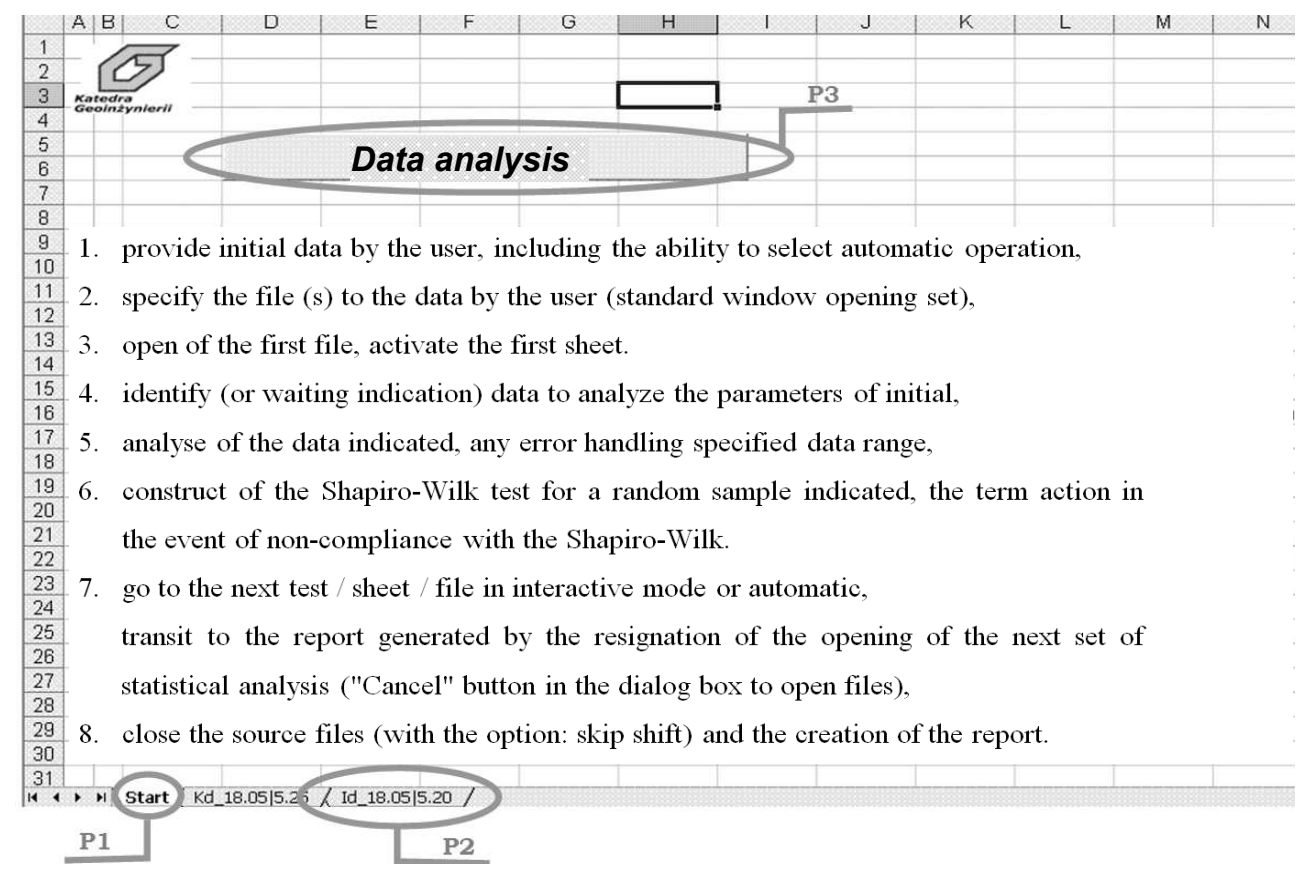

FIGURE 2. Main sheet of the BAYANAL code

\section{PROGRAM APPLICATION}

In Table 1 an example of a statistical analysis report for the three samples contained in two files is shown, one and two samples on separate sheets (one sheet of 1 sample in the first file, the second sheet of the two tests in a second file). Example of a Bayesian data analysis conducted is presented in Table 2. The report is supplemented with charts placed in a coordinate system (Fig. 3). The results of the analysis are illustrated by three curves that show the relationship between the mean values and confidence intervals/reliability of estimates of a classical analysis. Moreover, the curves illustrated not only the last test from classical analysis but also result of Bayesian analysis based on all attempts. The ranges of values for $\mathrm{x}$ and $\mathrm{y}$ axis are set automatically based on data obtained from the analysis. Graphs are placed on the same sheet as the resulting report. Sample charts for the above-described analysis are shown in Figure 3.

\section{CONCLUSION}

To determine the characteristic values of geotechnical parameters cautious use of statistical methods can be recommended. In current practice to determine the average value, standard deviation value with the required confidence level (e.g. 95\%) assumes a finite set of values derived from geotechnical parameters population. To determine the characteristic values, particularly strength and deformation of soils, it is proposed to use Bayesian analysis, in which there is pos- 
TABLE 1. Selection trials in the source worksheet, which is indicated on the form shown in Figure 3

\begin{tabular}{|c|c|c|c|c|c|c|c|c|c|c|c|c|c|c|c|c|}
\hline & A & $\theta$ & C & D & $E$ & $F$ & $G$ & $\mathrm{H}$ & 1 & $\mathrm{~J}$ & K & $L$ & $M$ & $\mathrm{~N}$ & 0 & $P$ \\
\hline 49 & 4,0 & 20,50 & 0,0748 & 0,010 & 0,0648 & 3,30 & 17,00 & & 13,700 & 0.291 & 1,652 & & 1,361 & 4,848 & 4,332 & 47,220 \\
\hline 50 & 4.1 & 20,50 & 0.0769 & 0.011 & 0,0659 & & & & & & & & & & & \\
\hline 51 & 4,2 & 19,50 & 0.0788 & 0.012 & 0,0668 & 2,00 & 13,00 & & 11,000 & 0,174 & 1.252 & & 1,077 & 6,642 & 2.428 & 37,382 \\
\hline 52 & 4,3 & 19,50 & 0,0807 & 0.013 & 0,0677 & & & & & & & & & & & \\
\hline 53 & 4,4 & 19,50 & 0,0827 & 0,014 & 0,0687 & 7,60 & 12,00 & & 4,400 & 0.767 & 1.152 & & 0,384 & 0.510 & 10,964 & 13,335 \\
\hline 54 & 4,5 & 19.50 & 0.0846 & 0.015 & 0,0696 & & & & & & & & & & & \\
\hline 55 & 4.6 & 19.50 & 0,0866 & 0.016 & 0.0706 & 4,00 & 7,90 & & 3,900 & 0.410 & 0.742 & & 0,332 & 0,843 & 5.576 & 11,513 \\
\hline 56 & 4.7 & 19,50 & 0,0885 & 0.017 & 0.0715 & & & & & & & & & & & \\
\hline 57 & 4,8 & 19,50 & 0.0905 & 0,018 & 0,0725 & 3,60 & 8.60 & & 5,000 & 0,364 & 0,812 & & 0.447 & 1,292 & 4,775 & 15,521 \\
\hline 58 & 4,9 & 19,50 & 0,0924 & 0.019 & 0,0734 & & & & & & & & & & & \\
\hline 59 & 5,0 & 19,50 & 0,0944 & 0.020 & 0,0744 & 4,10 & 8.40 & & 4,300 & 0.418 & 0,792 & & 0,374 & 0,940 & 5,345 & 12,971 \\
\hline 60 & 5.1 & 19.50 & 0.0963 & 0,021 & 0,0753 & & & & & & & & & & & \\
\hline 61 & 5,2 & 19,50 & 0,0983 & 0,022 & 0,0763 & 4,20 & 8,60 & & 4,400 & 0.427 & 0,812 & & 0,384 & 0,948 & 5.311 & 13,335 \\
\hline 62 & 5,3 & 19,50 & 0,1003 & 0,023 & 0,0772 & & & & & & & & & & & \\
\hline 63 & 5,4 & 19,50 & 0,1022 & 0,024 & 0,0782 & 3,30 & 8,50 & & 5,200 & 0,333 & 0,802 & & 0,468 & 1.515 & 3,954 & 16,250 \\
\hline 64 & 5,5 & 19,50 & 0,1042 & 0,025 & 0,0791 & & & & & & & & & & & \\
\hline 65 & 5,6 & 19,50 & 0,1061 & 0,026 & 0,0801 & 5,60 & 10,00 & & 4,400 & 0,567 & 0,952 & & 0,384 & 0.710 & 6.757 & 13,335 \\
\hline 66 & 5,7 & 19,50 & 0,1081 & 0,027 & 0,0810 & & & & & & & & & & & \\
\hline 67 & 5,8 & 19,50 & 0,1100 & 0,028 & 0,0820 & 4,80 & 9.50 & & 4,700 & 0.486 & 0,902 & & 0.416 & 0,908 & 5.582 & 14,428 \\
\hline 68 & 5,9 & 19,50 & 0,1120 & 0,029 & 0,0829 & & & & & & & & & & & \\
\hline 69 & 6,0 & 19,50 & 0.1139 & 0,030 & 0,0839 & 4,85 & 9.00 & & 4,150 & 0.493 & 0,852 & & 0,358 & 0.773 & 5,524 & 12.424 \\
\hline 70 & 6.1 & 19.50 & 0.1159 & 0,031 & 0,0848 & & & & & & & & & & & \\
\hline 71 & 6,2 & 19,50 & 0,1178 & 0,032 & 0,0858 & 5,80 & 10,30 & & 4,500 & 0,587 & 0,982 & & 0,395 & 0,712 & 8.485 & 13.700 \\
\hline 72 & 6,3 & 19,50 & 0.1198 & 0.033 & 0,0867 & & & & & & & & & & & \\
\hline 73 & 6.4 & 19,50 & 0.1217 & 0.034 & 0.0877 & 5,70 & 10,30 & & 4,600 & 0.576 & 0.982 & & 0.405 & 0.748 & 6.182 & 14,064 \\
\hline 74 & 6.5 & 19,50 & 0.1237 & 0,035 & 0,0886 & & & & & & & & & & & \\
\hline 75 & 6.6 & 19,50 & 0,1256 & 0,036 & 0,0896 & 5,50 & 9,90 & & 4,400 & 0,557 & 0,942 & & 0,384 & 0.737 & 5.817 & 13,335 \\
\hline 76 & 6.7 & 19,50 & 0.1276 & 0,037 & 0.0905 & & & & & & & & & & & \\
\hline 77 & 6.8 & 19,50 & 0.1295 & 0,038 & 0.0915 & 6,00 & 10,50 & & 4,500 & 0,607 & 1,002 & & 0,395 & 0,694 & 6.215 & 13.700 \\
\hline 78 & 6,9 & 20,00 & 0.1315 & 0,039 & 0,0925 & & & & & & & & & & & \\
\hline 79 & 7.0 & 20,00 & 0.1335 & 0,040 & 0,0935 & 5,50 & 10,50 & & 5,000 & 0,554 & 1.002 & & 0.447 & 0,870 & 5.499 & 15.521 \\
\hline 80 & 7.1 & 20,00 & 0,1355 & 0,041 & 0,0945 & & & & & & & & & & & \\
\hline 81 & 7,2 & 20,00 & 0,1375 & 0.042 & 0,0955 & 8,30 & \begin{tabular}{|l|}
13,00 \\
\end{tabular} & & 4,700 & 0,836 & 1.252 & & 0.416 & 0,524 & 8,311 & 14,428 \\
\hline 82 & 7,3 & 20,00 & 0.1395 & 0,043 & 0,0965 & & & & & & & & & & & \\
\hline 83 & 7.4 & 20,00 & 0,1415 & 0,044 & 0,0975 & 9,70 & 14,70 & & 5,000 & 0,974 & 1.422 & & 0.447 & 0.481 & 9,541 & 15,521 \\
\hline 84 & 7.5 & 20,00 & 0.1435 & 0.045 & 0,0985 & & & & & & & & & & & \\
\hline 85 & 7.6 & 20,00 & 0.1455 & 0.048 & 0,0995 & 6,00 & 11,00 & & 5,000 & 0,604 & 1.052 & & 0.447 & 0.801 & 5.610 & 15,521 \\
\hline 86 & 7.7 & 20,00 & 0.1475 & 0.047 & 0.1005 & & & & & & & & & & & \\
\hline 87 & 7.8 & 20,00 & 0,1495 & 0,048 & 0.1015 & 5,55 & 11,00 & & 5,450 & 0.557 & 1,052 & & 0.495 & 0.972 & 5.014 & 17.161 \\
\hline 88 & 7.9 & 20,00 & 0.1515 & 0,049 & 0.1025 & & & & & & & & & & & \\
\hline 89 & 8.0 & 20,00 & 0.1535 & 0.050 & 0.1035 & 4,7 & 8.5 & & 3,800 & 0.480 & 0,802 & & 0,321 & 0.747 & 4.157 & 11,149 \\
\hline 90 & 8.1 & 20,50 & 0.1556 & 0.051 & 0,1046 & & & & & & & & & & & \\
\hline
\end{tabular}

TABLE 2. Example of a Bayesian data analysis conducted

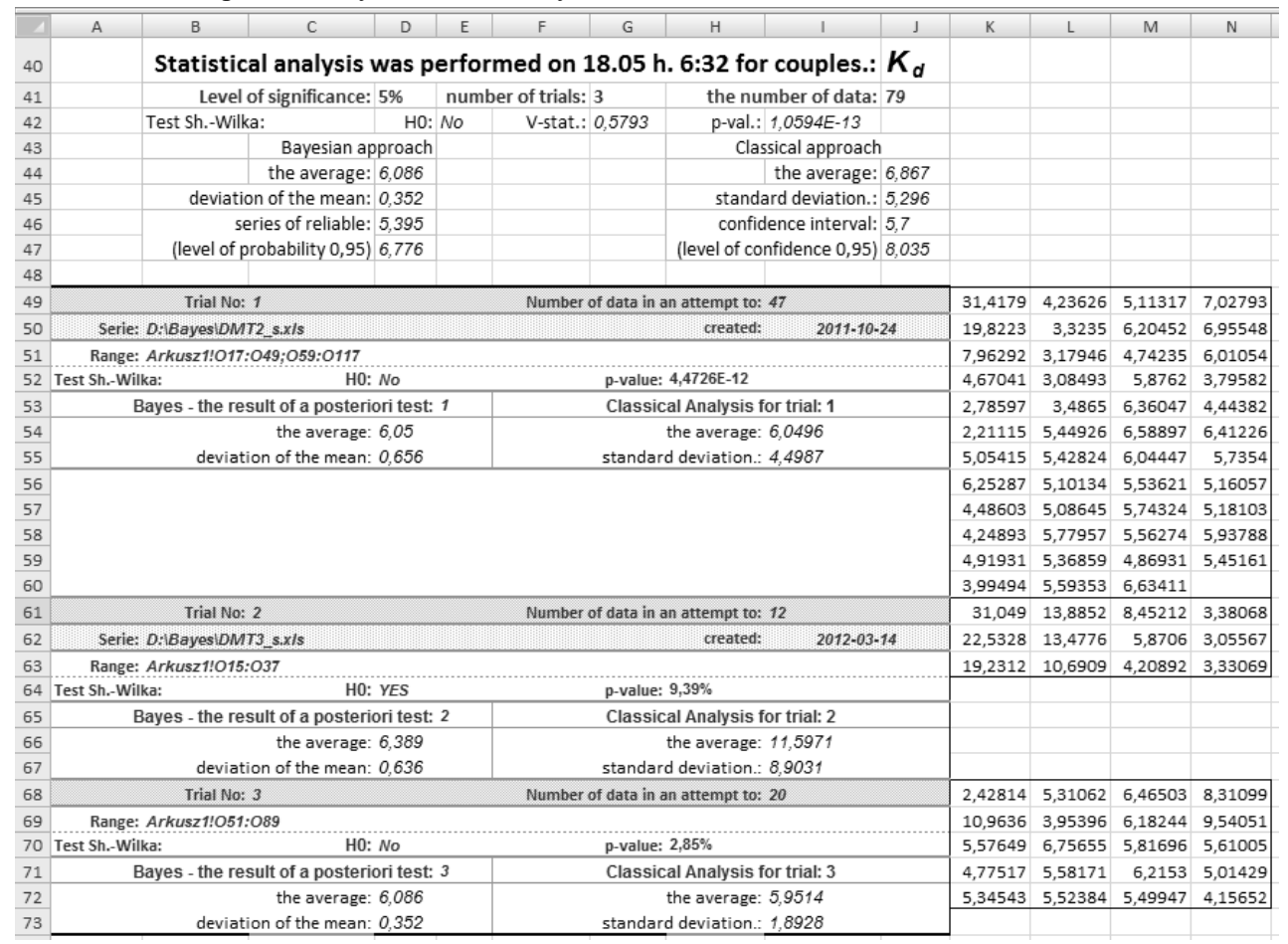




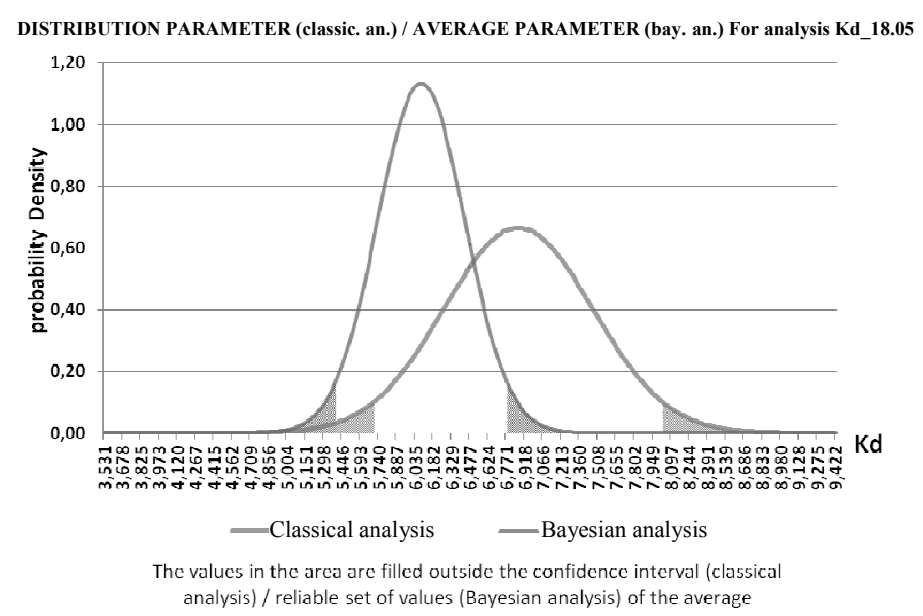

FIGURE 3. Charts illustrating the report of the data analysed

sible to continue data collection parameters derived according to the following formula:

$$
f(\theta \mid x)=\frac{f(x \mid \theta) \cdot f(\theta)}{\int_{\Omega} f(x \mid \theta) \cdot f(\theta) d \theta}
$$

where:

$x$ - result of the test (the value of the geotechnical parameters), $\theta$ - estimated parameter of the population, while $\theta_{i}$ are all possible parameter values $\theta$, after which the sum in the denominator runs.

The assignment of conditional probabilities $P\left(x \mid \theta_{i}\right)$ for all possible values of the unknown parameter $\theta$ is called the reliability function. Having therefore the result of observations of $x$ and knowing the likelihood function (for the observed result of $x$, but not for all possible observations!) as well as knowing a priori probability $\mathrm{P}\left(\theta_{i}\right)$ of adaption by the parameter $\theta$ of the possible values
- you can calculate the a posteriori probability of adapting a specific value for this parameter. Thus you can designate a posteriori probability distribution of this parameter.

Bayesian method is preferred when you want to include an objective a priori information about the parameter. You cannot use the classical approach, where only analyzed a random sample taken. It is also preferred the use of Bayesian approach, when we gradually turn to the analysis of a new data set (the idea of observation methods), for example, it can help you in choosing the number of probes required to obtain a satisfactory precision of the data. The analysis attempts do not need to dispose of a full knowledge of the samples, from which a priori information can be chosen. BAYANAL package can be widely used in geotechnical design practice in Poland in order to select a reliable geotechnical parameters for the design of safe buildings. 


\section{Acknowledgements}

This research was supported by two grants NCN: N N506 218039 and UMO2011/03/D/ST8/04309 from the Polish Ministry of Science and Higher Education.

\section{REFERENCES}

ALÉN C.G. 1998: On probability in geotechnics. Random calculation models exemplified on slope stability analysis and ground-superstructure interaction. Doctoral thesis. Chalmers University of Technology, Göteborg.

ALÉN C.G., SÄLLFORS G.B. 1999: Uncertainties in modeling of soil properties. Barends et al. (eds). Proc. of the EC SMGE: Geotechnical Engineering for Transportation Infrastructure, Balkema, Rotterdam, 303-308.

BOND A.J., HARRIS A.J. 2008: Decoding Eurocode 7. Taylor and Francis, London.

EN 1997-1: 2004: Eurocode 7 - Geotechnical design, Part 1: General rules.

EN 1997-2: 2007: Eurocode 7 - Geotechnical design. Part 2: Ground investigation and testing.

FRANK R., BAUDUIN C., DRISCOLL R., KAVVADAS M., KREBS OVESEN N., ORR T.L.L., SCHUPPENER B. 2004: Designers'guide to EN 1997-1, Eurocode 7: Geotechnical design. Part 1: General rules. Thomas Telford, London.

GARBULEWSKI K., JABŁONOWSKI S., RABARIJOELY S. 2007: Zastosowanie analizy bayesowskiej w projektowaniu geotechnicznym. Inżynieria Morska i Geotechnika 3, 163-169.

ORR T.L.L. 2005: Proceedings of International Workshop on Evaluation of Eurocode 7. Department of Civil, Structural and Environmental Engineering, Trinity College, Dublin.
PIECZYRAK J. 2009: Stany graniczne $i$ warunki obliczeniowe $w$ geotechnice. Proc. XXIV Ogólnopolskich Warsztatów Pracy Projektanta Konstrukcji, Wisła 2009, I, 247-270.

SCHNEIDER H.R. 1990: Die Wahl der Baugrundkennwerte. In: Anwendung der neuen Tragwerksnormen des SIA im Grundbau, Mitteilungen der Schweizerischen Gesell-schaft für Boden und Felsmechanik. SIA, Zürich.

SCHNEIDER H.R. 1997: Definition and determination of characteristic soil properties. Proc. XIV ICSMFE, Hamburg, Balkema, Rotterdam.

SCHNEIDER H.R. 2010: Characteristic soil properties for EC7: Influence of quality of test results and soil volume involved. Proc. $14^{\text {th }}$ Danube-European Conference on Geotechnical Engineering, 2 June 2010, Bratislava.

SCHNEIDER H.R., FITZE P. 2009: Charakteristische Baugrundwerte: Erfahrung, Versuchswerte und Statistik, Herbsttagung SBGF. 6 Nov. 2009, EPFL Lausanne.

SCHUPPENER B., SIMPSON B., ORR T.L.L., FRANK R., BOND A.J. 2009: Loss of static equilibrium of a structure - definition and verification of limit state $E Q U$. Proc. $2^{\text {nd }}$ Int. Symp. on Geotechnical Safety and Risk, Gifu, Japan.

UZIELLI M. 2008: Statistical analysis of geotechnical data. In: A.-B. Huang, P.W. Mayne (eds.) Geotechnical and geophysical site characterization. Taylor \& Francis Group, Abingdon Oxon.

WYSOKIŃSKI L., KOTLICKI W., GODLEWSKI T. 2011: Projektowanie geotechniczne wedtug Eurokodu 7. Poradnik. Instytut Techniki Budowlanej, Warszawa.

Streszczenie: Program BAYANAL w projektowaniu geotechnicznym wedlug Eurokodu 7. W projektowaniu geotechnicznym według Eurokodu 7 przy określaniu wartości charakterystycz- 
nych parametrów geotechnicznych, w tym wytrzymałościowych i odkształceniowych, należy w sposób ostrożny i przemyślany zastosować metody statystyczne, zarówno klasyczne, jak i tzw. bayesowskie. Analiza statystyczna Bayesa uzasadniona jest $\mathrm{w}$ przypadku posiadania i uwzględniania w doborze parametrów wartości a priori, na przykład wartości eksperckich parametrów geotechnicznych, lub w przypadku możliwości powiększania liczebności zbiorów parametrów i danych geotechnicznych, co stanowi podstawę projektowania metodą „obserwacyjną”. Do analizy statystycznej danych geotechnicznych zastosowano numeryczny pakiet BAYANAL. Pakiet BAYANAL może znaleźć szerokie zastosowanie w praktyce projektowania geotechnicznego w Polsce do doboru parametrów geotechnicznych miarodajnych do projektowania bezpiecznych obiektów budowlanych.

Stowa kluczowe: Eurokod 7, parametry gruntów, projektowanie geotechniczne, analiza bayesowska
Authors' address:
Katedra Geoinżynierii
Wydział Budownictwa i Inżynierii Środowiska SGGW
ul. Nowoursynowska 159, 02-776 Warszawa
Poland
e-mail: Simon_rabarijoely@sggw.pl 
